\title{
FEDERAL COURT POWER TO ADMIT TO BAIL STATE PRISONERS PETITIONING FOR HABEAS CORPUS
}

$I_{T}$ is WELL SETTLED that a state prisoner may test the constitutionality of his conviction by petitioning a federal district court for a writ of habeas corpus. ${ }^{1}$ Undetermined, however, is the power of federal courts to release the state prisoner on bail pending disposition of the petition. Recently, in Johnston v. Marsh, ${ }^{2}$ the United States Court of Appeals for the Third Circuit had before it petitions for prohibition and mandamus to expunge the order of a district court releasing on bail a state prisoner $^{3}$ who had petitioned for habeas corpus. ${ }^{*}$ The court of appeals, in denying the writs, held that the district court had acted within its jurisdiction. ${ }^{5}$

\footnotetext{
${ }^{1} 63$ STAT. 105 (1949), 28 U.S.C. $\$ 2241$ (1952). Writs of habeas corpus may be granted by the Supreme Court, any justice thereof, the district courts, and any judge of a court of appeals, within their respective jurisdictions. Cf. 62 STAT. 967 (1948), 28 U.S.C. $\$ 2254$ (1952). The exhaustion of state remedies is a prerequisite of relief by habeas corpus from a federal court. Ex parte Royall, II 7 U.S. 24I, 249 (I886); United States ex rel. Elliott v. Hendricks, 213 F.2d 922 (3d Cir. 1954), cert. denied 348 U.S. 851 (1954); United States v. Hayman, 342 U.S. 205 (1952). Cf. discussion by Justice Frankfurter in Brown v. Allen, 344 U.S. 443 (1953); Notes, 6o Harv. L. ReV. 8 II (1947), 49 Mich. L. Rev. 6II (1951), 34 MiNN. L. Rev. 653 (1950). 200 F.2d 528 ( 3 d Cir. 1955), noted in 42 VA. L. REv. 585 (1956).

${ }^{3}$ The relator and a co-defandant were tried jointly for ro6 separate indictments charging misconduct in public office. On appeal from a conviction and denial of a $110 w$ trial, it was asserted that the consolidated trial prejudiced the relator. The appellate court, however, affirmed the conviction, Commonwealth v. Ackerman, $176 \mathrm{~Pa}$. Super. 80, In6 A.2d 886 (1954); the Supreme Court of Pennsylvania denied appeal without opinion, Appendix to Brief for Petitioner, p. 5a, Johnston v. Marsh, 227 F.2d 528 (3d Cir. 1955); and the United States Supreme Court denied certiorari, 348 U.S. 95I (1955). The relator thereupon began serving his two-year jail sentence.

- United States ex rel. Ackerman v. Commonwealth, 133 F. Supp. 627 (W.D. Pa. 1955), noted in 69 HARv. L. REv. 752 (1956). The relator was suffering from advanced diabetes which seriously affected his vision and caused or contributed to numerous other ailments. He was, at the time of trial, practically blind in his left eye, and the condition of his right eye was progressively deteriorating. According to medical testimony, the relator had a fair probability of retaining the sight in his right eye with proper medical attention, but continued confinement would probably lead to total blindness.

'This was the only point decided. The court did not pass upon the propriety of the admission to bail: "We are not for a moment suggesting that the district court here did make a mistake. Neither are we saying that he was right. That point is not before us. What we are deciding is that the court was acting within its jurisdiction. Since it was acting within its jurisdiction the writs prayed for are inappropriate because
} 
It is conceded that no express statutory authorization supports the action of the district court; ${ }^{6}$ but it has been suggested that this support might be found elsewhere. For example, section 2243 of the Judicial $\mathrm{Code}^{7}$ requires that the district courts, in hearing habeas corpus petitions, "dispose of the party as law and justice require." Arguably, the bail power asserted in the Johnston case is implicit in this statutory directive. $^{8}$ A more acceptable justification, however, is suggested by the proposition that the power of a federal court to admit to bail depends not on statutory authorization, but is, instead, inherent in the court. This proposition finds support in language of an early Supreme Court case, ${ }^{9}$ in a recent opinion by Justice Douglas sitting as a circuit judge, ${ }^{10}$ and in several of the lower federal court cases which have considered the problem. ${ }^{11}$ In Principe v. Ault, ${ }^{12}$ for example, a federal district court, granting bail pending the hearing of an application for a writ of habeas corpus, justified its action, by reasoning that since a federal statute empowered the district courts to hear petitions for habeas corpus, the common law should define the manner in which that power could be exercised. ${ }^{13}$ It is clear that the common law courts had power to grant bail independent of any statute. ${ }^{14}$

Additional support for the conclusion that federal courts may admit prisoners to bail without express congressional authority is found in Supreme Court Rule $49{ }^{15}$ which regulates bail in the federal courts

prohibition and mandamus only run against the judge when he has acted beyond his judicial authority or has refused to act within it." 227 F.2d at 53 r.

${ }^{\circ}$ Brief for Respondent, pp. 7-8, Johnston v. Marsh, 227 F.2d 528 (3d Cir. 1955). See also the language of the court: "If there is found specific statutory authority for admission to bail in such a case as this, such a provision would end the matter." 227 F.2d at 530 .

${ }^{7} 62$ STAT. 965 (1948), 28 U.S.C. $\$ 2243$ (1952).

${ }^{8}$ This argument was accepted by the Court in the Jolnnston case. 227 F.2d at 530-3 I. The argument is criticized in 42 VA. L. REv. 585,587 (1956).

${ }^{\circ}$ In Wright v. Henkel, 190 U.S. 40, 63 (1903) (dictum), the Court said that it was "unwilling to hold that the Circuit Courts possess no power in respect of admitting to bail other than as specifically vested by statute. ..."

${ }^{10}$ Petition of Johnson, 72 Sup. Ct. I028 (1952). Justice Douglas stated that the power specified by the statutes and rules is not exclusive, and did not by implication deny a justice power to grant bail incident to ruling on the application.

${ }^{11}$ In re Gannon, 27 F.2d 362, 363 (E.D. Pa. 1928); Artukovic v. Boyle, 107

F. Supp. II (S.D. Cal. 1952); Ewing v. Unted States, 240 Fed. 241 (6th Cir. 1917).

${ }_{12} 62$ F. Supp. 279 (N.D. Ohio 1945 ), noted in 19 So. CALIF. L. Rev. 458 ( 1946 ).

${ }^{13} 62$ F. Supp. at 281 .

"14 The Queen v. Spilsbury, [1898] 2 Q.B. 615, 620 (dictum).

${ }^{16}$ U.S. SUP. CT. RULE 49, 28 U.S.C.A. (Supp. 1955). 
while appeals are pending from decisions involving the disposition of writs of habeas corpus. ${ }^{18}$ Since there does not appear to be any direct congressional authority for the bail power contained in this rule, if the rule is valid, it would follow that a bail power does inhere in the federal courts. ${ }^{17}$

Assuming, then, that the action of the district court in Johnston $v$. Marsh was not beyond its power, there remains the further question whether it is desirable for district courts to admit state prisoners to bail prior to the hearing on the habeas corpus petition. Some support for granting bail at this stage may perhaps be inferred from Supreme Court Rule 49, which provides that federal courts shall grant bail pending appeal of a decision discharging a prisoner on habeas corpus, and may grant bail pending appeal of a decision discharging a writ after it has been issued. ${ }^{18}$ That the rule authorizes bail regardless of what disposition is made of the writ after it has been issued would suggest the appropriateness of granting bail in advance of the hearing on the writ.

On the other hand, however, the fact that Rule 49 requires bail in certain instances and allows bail in others calls attention to a consideration which has an especial significance when the habeas corpus petitioner is a state prisoner. The distinction drawn by the rule undoubtedly was prompted by a recognition that the function of bail is to prevent the confinement of a prisoner before it is finally established that he should be confined. Accordingly, the rule evaluates the right to bail by the probability that the confinement is proper; and, presumably, a federal district court, when proceeding independently of the rule, should evaluate the right to bail in the same manner. When a state confinement is involved, however, the additional consideration of the sensitivity of the federal-state relationship should be taken into account. ${ }^{10}$

${ }^{16}$ The Third Circuit counterpart of U.S. SUP. Cr. RULE 49 is 3D CIR. RULE 15. The latter, however, is not a literal copy of the former. Rule 15 completely excludes paragraph 5 of Rule 49 , but the first four paragraphs are very similar. Cf. Pino v. Nicolls, 2 I I F.2d 393 (rst Cir. 1954), wherein the court declared that they were without power to prescribe a rule of procedure for the district court to admit to bail under Rule 45, the predecessor of Rule 49.

${ }^{17}$ See 69 Harv. L. Rev. 752, 753 (1956).

${ }^{18}$ See United States ex rel. Ackerman v. Commonwealth, I33 F. Supp. 627 (W.D. Pa. 1955).

${ }^{19}$ See United States ex rel. Elliott v. Hendricks, 213 F.2d 922 (3d Cir. 1954), in which the State of Pennsylvania, joined by the attorneys general of forty other states, opposed as unconstitutional this type of action by the federal district courts. See 25 State Govr. 249 (1952); Parker, Limiting the Abuse of Habeas Corpus, 8 F.R.D. 
The determination of a prisoner's guilt by state courts should carry with it, for purposes of bail, a presumption that the procedure was fair. Therefore, in evaluating the probability that a state confinement is proper, a federal court should give considerable deference to the state judicial machinery and should require a strong showing of irregularity before indulging the assumption upon which the grant of bail is necessarily premised. ${ }^{20}$ In this connection, it would hardly be relevant for the federal courts to take into account state bail policy, since that policy will be directed primarily to situations where the legality of confinement is largely undetermined. And even the state bail policy regarding habeas corpus petitions by convicted prisoners should not be particularly influential, since that policy does not take into account the importance of maintaining a satisfactory relationship between two independent court systems. ${ }^{21}$

In fact, it would appear doubtful that any showing made in an application for habeas corpus by a state prisoner could outweigh the importance of according a presumption of validity to the state procedure. Obviously, matters relating to the health of prisoners are to be regulated by means short of bail. ${ }^{22}$ Perhaps, then, the exercise of the inherent power to admit to bail, asserted by the court in the instant case, should have awaited a favorable disposition of the merits of the habeas corpus petition.

I7I (1948); Notes, 4 UTAH L. Rev. 260 (1954), 4 I Calif. L. Rev. 483 (1953). Cf. Note, 6 Duke B.J. 48 (1956).

${ }^{20}$ See 69 Harv. L. Rev. 752, 754 (1956).

${ }^{21}$ In the present case, the Pennsylvania statutes would prohibit bail in habeas corpus proceedings where the prisoner has been convicted and sentenced. Pa. Stat. AnN. tit. 12, §1905 (Purdon 1951).

${ }^{22}$ For discussion of the factors taken into consideration by the courts in past decisions, see Comment, 3 StaN. L. Rev. 167 (1950); Note, 27 ST. JohN's L. Rev. 56 (1952). 


\section{THE SEEMAN PRINTERY INCORPORATED}

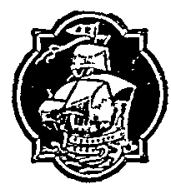

Manufacturing Printers

413 E. Chapel Hill Street

DURHAM, NORTH CAROLINA

\section{Any Single Copy of the

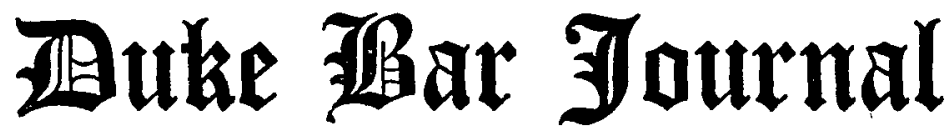

Is Available

Back Copies - . - . - . $\$ 1.25$

Current Numbers _. . . . $\$ 1.25$

(Effective January 1, 1956)

Address all inquiries to

The Managing Editor

DUKE BAR JOURNAL

School of Law, Duke University

Durham, North Carolina 